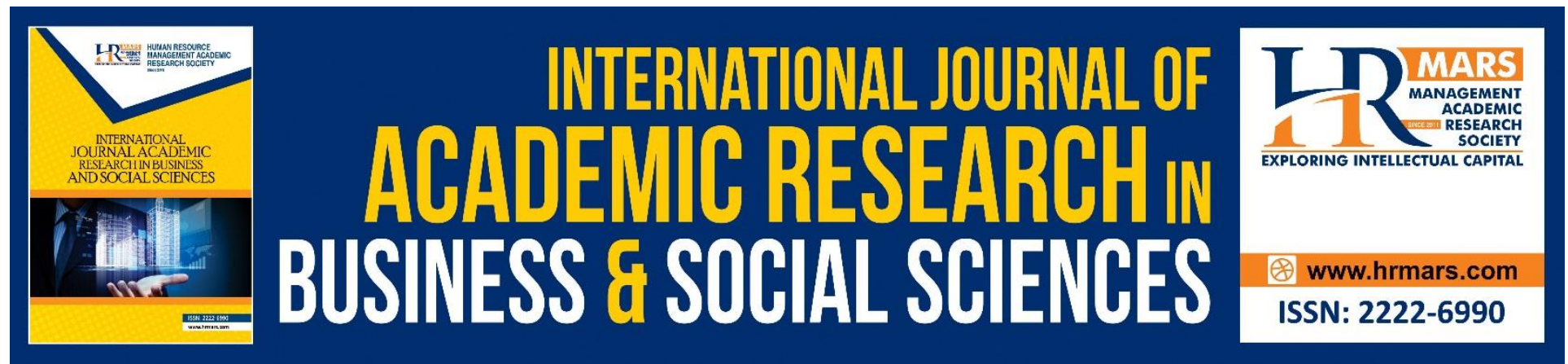

\title{
Stakeholder's Perception on Quality of Mergers and Acquisitions in Tanzania
}

\author{
Burhan Ahmad Mtengwa, Janeth A. Malleo
}

To Link this Article: http://dx.doi.org/10.6007/IJARBSS/v8-i10/4832

DOI: $10.6007 /$ IJARBSS/v8-i10/4832

Received: 12 Sept 2018, Revised: 21 Oct 2018, Accepted: 26 Oct 2018

Published Online: 06 Nov 2018

In-Text Citation: (Mtengwa \& Malleo, 2018)

To Cite this Article: Mtengwa, B. A., \& Malleo, J. A. (2018). Stakeholder's Perception on Quality of Mergers and Acquisitions in Tanzania. International Journal of Academic Research in Business and Social Sciences, 8(10), 1108-1124.

Copyright: (C) 2018 The Author(s)

Published by Human Resource Management Academic Research Society (www.hrmars.com)

This article is published under the Creative Commons Attribution (CC BY 4.0) license. Anyone may reproduce, distribute, translate and create derivative works of this article (for both commercial and non-commercial purposes), subject to full attribution to the original publication and authors. The full terms of this license may be seen

at: http://creativecommons.org/licences/by/4.0/legalcode

Vol. 8, No. 10, 2018, Pg. 1108 - 1124

http://hrmars.com/index.php/pages/detail/IJARBSS

JOURNAL HOMEPAGE

Full Terms \& Conditions of access and use can be found at http://hrmars.com/index.php/pages/detail/publication-ethics 


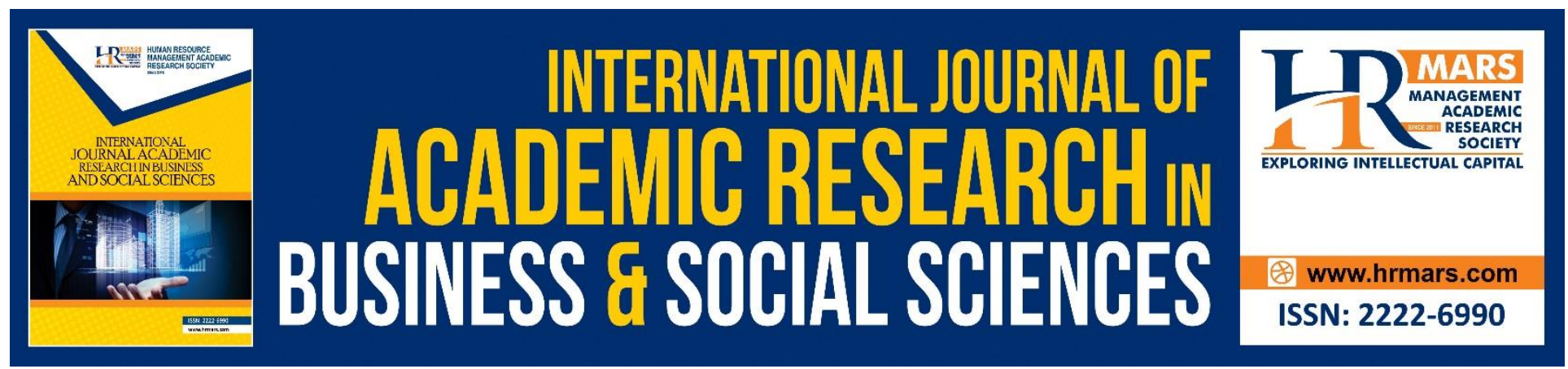

\title{
Stakeholder's Perception on Quality of Mergers and Acquisitions in Tanzania
}

\author{
Dr. Burhan Ahmad Mtengwa \\ Centre for Foreign Relations, Department of Economic Diplomacy, Po Box 2824 Dar es Salaam, \\ Tanzania \\ Email: mtengwa@hotmail.com \\ Janeth A. Malleo \\ Centre for Foreign Relations, Department of Economic Diplomacy, Dar es Salaam, Tanzania \\ Email: janee2malleo@gmail.com
}

\begin{abstract}
In the light of Mergers and Acquisitions movement, the purpose of this paper is to evaluate stakeholders' perception on the quality of mergers and acquisitions service sectors. It also seeks to measure the level of satisfaction among stakeholders towards mergers and acquisitions.

This paper employ SERVQUAL model to measure and evaluate stakeholders' expectation and perceptions on mergers and acquisition service sectors. Data were collected from a sample of 100 stakeholders from various merged and acquired banking, hotel and telecommunications companies in Dar-es-salaam, Tanzania by using questionnaires.

The findings reveal that all dimensions of mergers and acquisition service sector were not satisfactory to stakeholders. Gap score analysis indicated a negative values on all four dimensions namely job creation, market monopoly, customer satisfaction and shareholders position (employees feeling of betray by their employer, less job creations, a shift of stakeholder's bargaining power and less customers satisfaction) meaning that all dimensions needed improvements. Employment and shareholders' positions ranked high in importance weight analysis which also indicated that job creation and distribution of shares was not considerate.

The paper suggests involvements of stakeholders in the process and increase more job opportunities, shares and flexibility of market monopoly so as to improve mergers and acquisitions in Tanzania service sectors.

Practical Implications: The data provide evidences of less customers satisfaction on mergers and Acquisitions in service sectors in Tanzania. The findings have implications on companies which undergo mergers and acquisition to consider stakeholders concerns.
\end{abstract}

Keywords: Mergers, Acquisitions, Perception 
INTERNATIONAL JOURNAL OF ACADEMIC RESEARCH IN BUSINESS AND SOCIAL SCIENCES

Vol. 8, No. 10, Oct. 2018, E-ISSN: 2222-6990 @ 2018 HRMARS

\section{INTRODUCTION}

The goal of any business in a capitalist society is to maximize shareholder wealth and buying a company that helps accomplish that goal is seen as a good thing (Peavler, 2010). This is the broad financial definition of why companies merge. In the real world, there are actually many reasons that companies merge.

In early $19^{\text {th }}$ century, when M\&A movements were first noticed, small firms with little market share consolidated with similar firms to form large, powerful institutions that dominated their markets. It is estimated that more than 1,800 of these firms disappeared into consolidations, many of which acquired substantial shares of the markets in which they operated. Companies such as DuPont, US Steel, and General Electric that merged during this period were able to keep their dominance in their respective sectors through 1929, and in some cases today, due to growing technological advances of their products, patents, and brand recognition by their customers.

Furthermore, M\&A happened because of diversification reasons. Diversification is the reduction of risk through investment decisions. If a large, conglomerate firm thought that it had too much exposure to risk because it had too much of its business invested in one particular industry, it would buy a business in another industry. That would provide a measure of diversification for the acquiring firm. In other words, the acquiring firm no longer had all its eggs in one basket.

Today, Business firms may merge for other reasons despite fear of competition or diversification. In our diverse economic and political climate, they may be able to reduce risk by merging with firms even in other countries. This gives the benefit of reducing foreign exchange risk and localized recessions (Peavler, 2010). Most recently for example Deutsche Telekom have merged with Metro PCS, Google have merged with Motorola Mobility and Microsoft Corporation have acquired Skype and merged with Nokia Handset and Services Business.

In Tanzania mergers and acquisitions are guided by the legal framework which consists of the Fair Competition Act 2003, the Companies Act 2002, the Capital Markets and Securities (Substantial Acquisitions, Takeovers and Mergers) Regulations 2006, sector legislation such as the Energy and Water Utilities Authority Act 2001, the Tanzania Communications Authority Act 2003 and other more general statutes such as the Income Tax Act 2004 and the Employment and Labour Relations Act 2004.

According to Mkono and Ache (2009) mergers and acquisitions are regulated by the Fair Competition Act 2003 ('the Competition Act') through its implementing bodies: the Fair Competition Commission and the Fair Competition Tribunal. The Competition Act defines 'merger' as an acquisition of shares, a business or other asset, whether inside or outside Tanzania, resulting in the change of control of a business, part of a business or an asset of a business in Tanzania. UNCTAD policy review of 2012 explained that section 11(1) of the Act brings out the substantive test that a merger is prohibited if it creates or strengthens a position of dominance in a market, shareholders or stakeholders; of which dominance has a 35 per cent threshold. Stopping a merger simply because it would lead to a 35 per cent market share may prevent mergers that actually enhance efficiency.

It however envisaged that, changes in company's institutionalism, most especially by mergers and acquisition processes, may directly or indirectly affect the fate of company's stakeholders. Van den Berg (2012) identified that a most likely negative impact on stakeholders due to takeovers and mergers is associated with job losses in the acquired business (a direct result of cost synergies) and knock on effects on local economy; uncertainty and more job insecurity, particularly as organizational structures and systems are integrated; dissatisfaction of services and potential closure and / or transfer of capacity to other international locations (e.g. to emerging markets). 
With the influx of mergers and acquisition in Tanzania, it was therefore an attention of this study to evaluate stakeholders' perceptions on mergers and acquisition in Tanzania services sectors.

It can be noted however, despite prevailing rules and regulations set in every law above, companies stakeholders have to be considered when M\&A procedures are taking place. All stakeholders are affected in some way by a takeover or merger, and some, more than others. For stakeholders of the target business, the effect (and response) is often negative (Van den Berg, 2012). The key aim of this study was therefore, to evaluate stakeholders' perceptions regarding M\&A in Tanzania service sectors.

Thus the paper intends to address the following in details; first to evaluate stakeholder's perception on the quality of mergers and acquisition service sectors. Secondly to determine the level of stakeholders' satisfaction towards mergers and acquisition.

\section{RELATED LITERATURE REVIEW}

The two concept mergers and acquisition in many literatures are uses interchangeable and associate with other terms such as take over and amalgamation. In economic life of any firm mergers and acquisition play fundamental role of performance and growth. The terms mergers and acquisition can be understood in a very broad sense, as noted by Picot (2000) mergers and acquisition can be in quantity of different transactions such as concentration of undertakings, sales and purchases of undertakings, cooperation, privatization, alliances, joint ventures, management buy-outs and buy-ins as well as going public and also it is an instrument for managers to make decisions about reallocating resources (Hauser 2000, Haspeslagh \& Jemison, 1992 Palter \& Srinivasan, 2006). What aver it are mergers and acquisition is frontier for a firm success in any competitive environment. For the context of this paper mergers is define as combination of two or more company in on which only one will go into existence, this definition is allied with Foster Reed, Reed Lajoux, \& Nesvold, (2007) and Machiraju (2003), to gother they define a merger as combination of two or more companies in such a way that only one survives while the other is dissolved. In actual sense when two companies differ significantly in size on same industry they usually merge. On other hand acquisition can be describe as process whereby stocks or assert of a corporation come to be owned by the buyer. Acquisitions describe the process whereby stocks or assets of a corporation come to be owned by the buyer, the process enable a company to achieve a managerial influence (Foster Reed et al., 2007). In most case acquisitions can result into, whether the acquired institutions are consolidated into one single institution or continue to operate as separate entities under new ownership (Pilloff \& Santomero, 1996). However ,Jagersma, (2005) explain that acquisition may not necessarily be by mutual agreement.

\section{Types of Mergers and Acquisition}

There are two main types of mergers and acquisitions, firstly congeneric mergers and acquisitions and secondly conglomerate mergers and acquisitions. The congeneric mergers and acquisitions are classified into horizontal and vertical mergers and acquisitions. Horizontal mergers and acquisitions happens when the two companies that is going to be merged are from same industry, and most probably are competitors (chunlai chen and findlay, 2003). Horizontal mergers and acquisitions are mainly driving for a firm to achieve cost saving, increase market and to tap into new market segment. It is common practice globally and popular in business world. Horizontal mergers and acquisitions is common practice in automotive, pharmaceutical and petroleum industry on both domestic and cross border. Manda (2007) give example of horizontal merger on glaxo wellcome and smithkline beecham when they merge in year 1999 to form a new company named glaxosmithkline. As further explain by Chunlai Chen and Findlay (2003) that a 
vertical mergers and acquisitions happens when the acquirer and company being acquired are having business relationships of upstream supplier and downstream buyer in the value chain. Vertical mergers and acquisitions usually are driven by intention to reduce dependencies and reduction of overhead cost and gaining the scale of economies. For example a soft drink company buying a bottle manufacturing company as vertical mergers and acquisitions. Gaughan (2002) explain that conglomerate mergers and acquisitions occurs when the two companies that were involved in the mergers and acquisitions process are from irrelevant industry, with the purpose to diversify capital investment hence diversifying risk, and also to achieve scale of economies.

\section{Motives and Theories types of mergers and acquisition}

A range of literature review have place a significant effort in elaborating for mergers and acquisitions motive however there is no general rule on how the firm can execute mergers and acquisitions. This is because the intention for formulation mergers and acquisitions, might determine the whole process mergers and acquisitions. It might be possible that this intention is derive from many motives of mergers and acquisitions as identified below:

- A common motive of mergers and acquisitions is achieving economy scale and economy.

- To capture bigger market shares.

- Synergy is common motive to engage mergers and acquisitions.

- To promote knowledge and resource transfer.

- To reduce double marginalization, this is obviously seen in vertical mergers and acquisitions.

- Mergers and acquisitions also allow the new combined entity to perform asset restructuring.

-

For a firm to have specific motive is much depending on intention and nature of mergers and acquisitions. Merger motives have triggered far less theoretical efforts than merger consequences. But still the field has brought forth many different theories. Most observers agree that mergers are driven by a complex pattern of motives, and that no single approach can render a full account (Steiner, 1975; Ravencroft and Scherer, 1987). Table 1 below illustrates the various mergers and acquisitions motive theories. 
Table 1; MERGERS THEORIES

\begin{tabular}{|c|c|c|c|c|}
\hline THEORY & $\begin{array}{l}\text { DESCRIPTI } \\
\text { ON }\end{array}$ & MOTIVE & BENEFITS & $\begin{array}{l}\text { PROPOUN } \\
\text { D }\end{array}$ \\
\hline $\begin{array}{l}\text { Efficienc } \\
\text { y Theory }\end{array}$ & $\begin{array}{l}\text { Net gains } \\
\text { through } \\
\text { synergies }\end{array}$ & $\begin{array}{l}\text { Synergy;- } \\
\text { - More profitable } \\
\text { single entity than } \\
\text { separate parts } \\
\text { - Elimination of } \\
\text { inefficiencies } \\
\text { - Can be achieved } \\
\text { through } \\
\text { economies of } \\
\text { scale } \\
\text { - Can be achieved } \\
\text { through } \\
\text { economies of } \\
\text { scope }\end{array}$ & $\begin{array}{l}\text { Merger } \\
\text { benefits } \\
\text { bidder's } \\
\text { shareholder } \\
\mathrm{s}\end{array}$ & $\begin{array}{l}\text { Teece, } \\
1987 . \\
\text { Gaughan, } \\
1999 . \\
\text { Asquith, } \\
1983 . \\
\text { Sanchez, } \\
1999 ; \\
\text { Mester, } \\
1987 .\end{array}$ \\
\hline $\begin{array}{l}\text { Monopol } \\
\text { y Theory }\end{array}$ & $\begin{array}{l}\text { Wealth } \\
\text { transfer } \\
\text { from } \\
\text { customer }\end{array}$ & $\begin{array}{l}\text { Monopoly } \\
\text { on industry } \\
\text {;- } \\
\text { - Desire to become } \\
\text { market leader } \\
\text { - Achieved } \\
\text { through } \\
\text { horizontal } \\
\text { integration }\end{array}$ & $\begin{array}{l}\text { Merger } \\
\text { benefits } \\
\text { bidder's } \\
\text { shareholder } \\
\mathrm{s}\end{array}$ & $\begin{array}{l}\text { Gilbert \& } \\
\text { Newbery, } \\
1992 \\
\text { Eckbo, } \\
1983 . \\
\text { Kim \& } \\
\text { Singal, } \\
\text { 1993. }\end{array}$ \\
\hline $\begin{array}{l}\text { Raider } \\
\text { Theory }\end{array}$ & $\begin{array}{l}\text { Wealth } \\
\text { transfers } \\
\text { from } \\
\text { sharehold } \\
\text { ers }\end{array}$ & & $\begin{array}{l}\text { Merger } \\
\text { benefits } \\
\text { bidder's } \\
\text { shareholder } \\
\mathrm{s}\end{array}$ & \\
\hline $\begin{array}{l}\text { Valuatio } \\
\text { n Theory }\end{array}$ & $\begin{array}{l}\text { Net gains } \\
\text { through } \\
\text { private } \\
\text { informatio } \\
\mathrm{n}\end{array}$ & & $\begin{array}{l}\text { Merger } \\
\text { benefits } \\
\text { bidder's } \\
\text { shareholder } \\
\mathrm{s}\end{array}$ & \\
\hline $\begin{array}{l}\text { Empire } \\
\text { building } \\
\text { theory }\end{array}$ & & $\begin{array}{l}\text { Mangers } \\
\text { utility:- } \\
\text { - Managers have } \\
\text { private and } \\
\text { personal reason }\end{array}$ & $\begin{array}{l}\text { Merger } \\
\text { benefits } \\
\text { managers }\end{array}$ & $\begin{array}{l}\text { Gammelga } \\
\text { ard, } 1999 . \\
\text { Ravenscraf } \\
\text { t } \quad \&\end{array}$ \\
\hline
\end{tabular}




\begin{tabular}{|c|c|c|c|c|}
\hline & & $\begin{array}{l}\text { for their } \\
\text { behavior } \\
\text { - Hubris reason } \\
\text { - Executive } \\
\text { compensation }\end{array}$ & & $\begin{array}{l}\text { Scherer, } \\
1987 . \\
\text { Roll, } 1986 . \\
\text { Baumol, } \\
1959 .\end{array}$ \\
\hline $\begin{array}{l}\text { Process } \\
\text { theory }\end{array}$ & $\begin{array}{l}\text { Mergers } \\
\text { as } \\
\text { strategic } \\
\text { decision }\end{array}$ & $\begin{array}{l}\text { Growth;- } \\
\text { - Main strategy by } \\
\text { companies } \\
\text { - Decision is down } \\
\text { to whether it will } \\
\text { be through } \\
\text { - internal or } \\
\text { external means } \\
\text { - Accessing new } \\
\text { markets }\end{array}$ & $\begin{array}{l}\text { Merger as } \\
\text { process } \\
\text { outcome }\end{array}$ & $\begin{array}{l}\text { Starbuck, } \\
1965 . \\
\text { Hallen \& } \\
\text { Wiedershei } \\
\text { m-Paul, } \\
1982 .\end{array}$ \\
\hline $\begin{array}{l}\text { Disturba } \\
\text { nce } \\
\text { theory }\end{array}$ & $\begin{array}{l}\text { Changes } \\
\text { in } \\
\text { individual } \\
\text { expectatio } \\
\text { ns and } \\
\text { increase } \\
\text { of } \\
\text { uncertaint } \\
\text { y. }\end{array}$ & $\begin{array}{l}\text { Diversificati } \\
\text { on;- } \\
\text { - Desire to } \\
\text { minimise risk and } \\
\text { uncertainties } \\
\text { - Achieved } \\
\text { through } \\
\text { diversification or } \\
\text { conglomerate } \\
\text { - mergers }\end{array}$ & $\begin{array}{l}\text { Merger as } \\
\text { macroecono } \\
\text { mic } \\
\text { phenomeno } \\
\mathrm{n}\end{array}$ & $\begin{array}{l}\text { Pfeffer \& } \\
\text { Salancik, } \\
1978 . \\
\text { Lewellen, } \\
1971 . \\
\text { Weston \& } \\
\text { Mansignhk } \\
\text { a, 1971. } \\
\text { Gort, } 1974 .\end{array}$ \\
\hline
\end{tabular}

Motive Anyway, mergers and acquisitions motive involved in every mergers and acquisitions are very different, due to the unique nature of mergers and acquisitions. Therefore, most mergers and acquisitions study has focused on studying the outcome rather than motives. Hence, there is no any one size fits all mergers and acquisitions motive theory that applies to all mergers and acquisitions.

As illustrates in above table mergers and acquisitions motives theories are summaries below as depicted from:-

- Efficiency Theory - it views mergers as being planned and executed to achieve synergies.

- Monopoly Theory - it views mergers as being planned and executed to achieve market power.

- Raider Theory - this merger will trigger wealth transfers from the stockholders of the companies it bids for.

- Valuation Theory - it argues that mergers are planned and executed by managers who have better information about the target's value than the stock market.

- Empire building theory - it argues that mergers are planned and executed by managers who thereby maximise their own utility instead of their shareholders' value.

- Process theory - it views mergers as strategic decisions not as comprehensive rational choices but as outcomes of processes influenced by decision process, organisational routine and political power.

- Disturbance theory - it views merger waves as being caused by economic disturbances. 


\section{Measuring Quality of Mergers and Acquisition}

The measurements of service quality traditionally base on the concept of perception versus expectation gap analysis, expectations are viewed as desires or wants of customers. In measuring services quality some disagreements has stem on the nature and contents of service quality dimensions. For instance Parasuraman et al, (1988) use five dimension to measure service quality which include; empathy, responsiveness, tangibles and assurance, but Gronroos, (1984) use two dimension to measure service quality which include; technical quality and functional quality, Lastly Lethinen and Lehtinen (1991) proposed a three dimension to measure service quality which include; physical quality-physical environment, interactive quality - provider interaction/customer participation fit and corporate quality corporate image. This study is aim to measure quality of merger and acquisition base on various literatures we proposed for dimension of measuring quality of merger and acquisition job creation, market monopoly, customer satisfaction and shareholder position.

\section{- Job Creation}

In general many associate the mergers and acquisitions with employment losses, but in reality the process has significance positive and negative effects on jobholders. Shleifer and Summers (1988) note that mergers and acquisitions constitute a transfer of wealth from workers to shareholders. On the other hand, some economic theories predict that mergers and acquisitions can benefit workers (Jovanovic and Rousseau ,2002, 2004).

\section{- Shareholder position}

The process and outcome of mergers and acquisition have significance meaning to the acquirer and the acquire shareholder. Li (2016) note that in many mergers the shareholder wealth has increase but decreases efficiency for the target firm. Inversely shareholder wealth is decreased for an acquiring firm as an excessive bid premium is paid over the pre-bid price in order to persuade target shareholders to sell their shares to the acquiring firm (Li 2016). Manu literature suggests there is positive or negative impact on shareholder on mergers and acquisition process. (Neelam Rani, Surendra S Yadav, and P K Jain, 2015).

\section{- Market Monopoly}

Firm use merger and acquisition in order to increase their market strength and definite will enlarge their monopoly power which will enable to establish the prices for commodities at an unsustainable level within a more competitive market (Sehleana,2014). The nature of monopoly course with mergers and acquisitions can potentially reduction competition and an increase in prices charged to the consumer Ross et. al. (1996) emphasize that if the merger of two firms reduces competition it has to face legal challenges from regulatory authority.

\section{- Customer Satisfaction}

Broom of literature stress customer satisfaction on mergers and acquisitions, for instance Bekier and Shelton (2002) reported on the considerable risk of customers being lost in M\&A. Selden and Colvin (2003) advocated a customer perspective to M\&A. The thought of customers as an influence on M\&A performances is not new. As Rydén (1971) wrote:"The market share of an acquired 
company cannot automatically be transferred to the buyer without losing some part of the market. To achieve positive coordination gains, standardization of the product range could mean losing customers. The acquiring company might for some customers only represent the second best buying alternative after a merger due to the customers buying habits, brand loyalty, etc. To achieve coordination gains, the distribution system might have to be rearranged and the mergered company might have to deliberately let go of a part of the total market. Of course, the loss of market varies from case to case. Unsystematically collected interview statements indicate that the loss could be substantial. Figures of 25 to 50 percent of the acquired company's market have been mentioned." On the other hand, in press releases announcing mergers or acquisitions it is often stated, that "it is for the good of the customers" and the consumers are sometimes viewed as the greatest beneficiary of the M\&A activities (Christina Öberg and Helén Anderson, 2002).

\section{Mergers and Acquisition in Tanzania}

As of 12 June 2009 the Tanzanian exchange had 10 listed companies with one pending (CRDB Bank) and four cross-listed companies worth approximately US\$ $4 \mathrm{bn}$. Acquisitions and mergers involving public listed companies are governed by the Capital Markets and Securities (Substantial Acquisitions, Takeovers and Mergers) Regulations 2006 ('the Regulations') which came into force in December 2006 (Mkono and Ache, 2009).

The Regulations mainly apply to acquisitions of an interest of between 20 and 75 percent in public or listed companies and to mergers meeting such thresholds. A specialized committee, the Prospectus Evaluation Committee, is responsible for reviewing applications, pending the creation of a specialized Mergers and Acquisition Committee. The Regulations contain: (i) lengthy and detailed provisions that ensure a transparent and efficient offering system; (ii) restrictions on dealings before, during and after the offering; and (iii) shareholder disclosure requirements.

The acquisition of an interest of more than 90 percent triggers the mandatory takeover and delisting sections of the Regulations. This means that the acquirer must either make a mandatory public takeover offer to all shareholders of the target or disinvest through an offer for sale or by a fresh issue of capital to the public in order to fall below the threshold. 
INTERNATIONAL JOURNAL OF ACADEMIC RESEARCH IN BUSINESS AND SOCIAL SCIENCES

Vol. 8, No. 10, Oct. 2018, E-ISSN: 2222-6990 @ 2018 HRMARS

Table 1 List of Approved Mergers and Acquisition in Service Sector (2006 - 2010)

\begin{tabular}{|c|c|c|c|c|c|}
\hline $\begin{array}{l}\mathrm{S} / \\
\mathrm{N}\end{array}$ & $\begin{array}{l}\text { APPLICATI } \\
\text { ON DATE }\end{array}$ & ACQUIRING FIRM (PURCHASERS) & TARGET FIRM & $\begin{array}{ll}\text { FORM } & \text { OF } \\
\text { TRANSACTION } & \end{array}$ & $\begin{array}{l}\text { STAT } \\
\text { US }\end{array}$ \\
\hline 1 & $28 / 06 / 06$ & $\begin{array}{l}\text { Business Connexion Group Limited } \\
(\mathrm{BCX})\end{array}$ & BCT and JEDI & Group restructuring & $\begin{array}{l}\text { Approved on } \\
23 / 01 / 2007\end{array}$ \\
\hline 2 & $16 / 07 / 07$ & $\begin{array}{l}\text { Modern Africa one, Wilken Africa } \\
\text { Limited, Milas Limited, Stelsat Limited } \\
\text { and MultiChoice Africa Limited (MAL) }\end{array}$ & $\begin{array}{l}\text { Afsat Communications } \\
\text { Limited (ACL) }\end{array}$ & $\begin{array}{l}\text { Sale and Purchase of } \\
\text { shares }\end{array}$ & $\begin{array}{l}\text { Approved on } \\
11 / 09 / 2007\end{array}$ \\
\hline 4 & 09/08/07 & $\begin{array}{l}\text { Trans Century Limited } \\
\text { (TCL) }\end{array}$ & $\begin{array}{l}\text { Asea Brown Boveri } \\
\text { Limited (ABB) }\end{array}$ & $\begin{array}{l}\text { Sale and Purchase of } \\
\text { shares }\end{array}$ & \\
\hline 5 & $25 / 09 / 07$ & $\begin{array}{l}\text { Marc Group Limited and } \\
\text { Heritage Insurance } \\
\text { Company Tanzania Limited }\end{array}$ & $\begin{array}{l}\text { Strategis Insurance } \\
\text { Tanzania Limited }\end{array}$ & $\begin{array}{l}\text { Sale and Purchase of } \\
\text { shares }\end{array}$ & $\begin{array}{l}\text { Approved on } \\
28 / 09 / 2007\end{array}$ \\
\hline 6 & 06/11/07 & ATMT(Holdings) Limited & SimbaNet $(T)$ Limited & $\begin{array}{l}\text { Sale and purchase of } \\
\text { shares }\end{array}$ & $\begin{array}{l}\text { Approved on } \\
18 / 01 / 2008\end{array}$ \\
\hline 7 & $27 / 03 / 08$ & $\begin{array}{l}\text { Barry Calleabut Sourcing } \\
\text { AG }\end{array}$ & $\begin{array}{l}\text { Biolands International } \\
\text { Ltd }\end{array}$ & $\begin{array}{l}\text { Sale and purchase of } \\
\text { shares }\end{array}$ & $\begin{array}{l}\text { Approved on } \\
01 / 04 / 2008\end{array}$ \\
\hline 8 & $12 / 06 / 08$ & $\begin{array}{l}\text { Synovate (Holdings) } \\
\text { Limited }\end{array}$ & $\begin{array}{l}\text { The Steadman Group } \\
\text { (T) Limited }\end{array}$ & $\begin{array}{l}\text { Sale and purchase of } \\
\text { shares }\end{array}$ & $\begin{array}{l}\text { Approved on } \\
25 / 06 / 2008\end{array}$ \\
\hline 9 & $14 / 08 / 08$ & Vodacom Group Pty & $\begin{array}{l}\text { Gateway } \\
\text { Telecommunications } \\
\text { PLC }\end{array}$ & $\begin{array}{l}\text { Sale and acquisition of } \\
\text { Subsidiaries }\end{array}$ & $\begin{array}{l}\text { Approved on } \\
22 / 10 / 2008\end{array}$ \\
\hline 10 & $13 / 11 / 2008$ & Vodafone Group PLC & Telkom SA Ltd & $\begin{array}{l}\text { Sale and acquisition of } \\
\text { shares }\end{array}$ & $\begin{array}{l}\text { Approved on } \\
21 / 11 / 2008\end{array}$ \\
\hline 11 & $05 / 12 / 08$ & $\begin{array}{l}\text { Eagle Africa Insurance } \\
\text { Brokers(Kenya)Limited }\end{array}$ & $\begin{array}{l}\text { Eagle Africa Insurance } \\
\text { Brokers(T)Limited }\end{array}$ & $\begin{array}{l}\text { Sale and purchase of } \\
\text { shares }\end{array}$ & $\begin{array}{l}\text { Approved on } \\
23 / 12 / 2008\end{array}$ \\
\hline 12 & $13 / 01 / 2009$ & $\begin{array}{l}\text { Telkom International (Pty) } \\
\text { Ltd }\end{array}$ & M-Web Africa Limited & $\begin{array}{l}\text { Sale and purchase of } \\
\text { shares }\end{array}$ & $\begin{array}{l}\text { Approved on } \\
24 / 02 / 2009\end{array}$ \\
\hline 13 & $05 / 03 / 2009$ & NIC Bank Limited & $\begin{array}{l}\text { Savings and Finance } \\
\text { Commercial Bank } \\
\text { Limited }\end{array}$ & $\begin{array}{l}\text { Sale and purchase of } \\
\text { shares }\end{array}$ & $\begin{array}{l}\text { Approved on } \\
24 / 03 / 2009\end{array}$ \\
\hline 14 & $11 / 06 / 2009$ & $\begin{array}{c}\text { I\&M Bank Limited and The } \\
\text { Kibo Fund LLC }\end{array}$ & CF UNION & $\begin{array}{l}\text { Sale and Purchase of } \\
\text { shares }\end{array}$ & $\begin{array}{l}\text { Approved on } \\
16 / 11 / 2009\end{array}$ \\
\hline 15 & $08 / 04 / 2010$ & $\begin{array}{l}\text { Bharti Airtel International } \\
\text { (Netherlands) BV }\end{array}$ & Zain Africa BV & $\begin{array}{l}\text { Purchase and Sale of } \\
\text { shares }\end{array}$ & $\begin{array}{l}\text { Approved on } \\
27 / 04 / 2010\end{array}$ \\
\hline
\end{tabular}

Source: Fair Competition Commission, 2013. 
INTERNATIONAL JOURNAL OF ACADEMIC RESEARCH IN BUSINESS AND SOCIAL SCIENCES

Vol. 8, No. 10, Oct. 2018, E-ISSN: 2222-6990 @ 2018 HRMARS

\section{Position of Stakeholders after Mergers and Acquisition Procedures}

According to Vossos (2011), acquisition procedures can subsequently affect the fate of companies' stakeholders. Acquisition acts are an ordinary occurrence in the world of business, but massively important for the stakeholders, those affected by the actions of a business (such as shareholders, employees and clients). An acquisition can take place by buying either a firm's shares or its assets, but both methods result in the acquiring company taking control.

Shareholders. The shareholders of the acquired company are the winners in an acquisition agreement, especially if the shares of the organization had no prospect of rising. They have the opportunity to sell their shares and search for other, more profitable opportunities. Especially if the buyer miscalculates the acquired firm's value, then its shareholders can also make a small profit out of the acquisition. However, the shareholders of the acquiring firm may have to deal with a debt load the acquiring firm needed to fund the takeover. The higher the liabilities, the lower the shareholders' equity (as assets - liabilities = equity).

Management. The management structure and methods are the first to change in an acquisition. Acquiring firms have to take over the combined company as the legitimate owners, but the managers of acquired firms know their company better. This is a balance the new management has to keep, even though a large team (combining both companies' management teams) can be a costly and unwieldy option. Therefore, layoffs or demotions of former top executives are first on the agenda of the new management.

Employees. Employees are directly affected by an acquisition. This is because the new management may have different plans for the newly acquired assets. Changes in the production process (for example, changing the focus from computer hardware to software) or even scheduled cuts can cost the jobs of employees. However, acquisitions may also be beneficiary for workers, as the new management can introduce the higher salaries of the acquiring firm and a better employee code of conduct.

Customers. Acquisitions can also affect customers who trusted the acquired firm. This is because the products of acquired companies may be altered in quality and price. On such occasions, customers can change their consuming habits, buying more of a cheaper or high-quality product or less of an expensive or low-quality one. In case an acquiring firm decides to abandon a product or service altogether, formerly loyal customers have to search elsewhere to satisfy their needs.

\section{METHODOLOGY}

To achieve the objectives of the research a survey was conducted in various merged and acquired service companies in Dar es Salaam, Tanzania. The total number of questionnaires applied was 100, from which stakeholders were asked to evaluate their expectations and their perceptions related to mergers and acquisition service sectors. The questionnaire design was based on the SERVQUAL method utilized to determine the services quality.

\section{Sample and Population}

The population for the study was banks, hotels and telecommunication companies located in Dar-essalaam who are the commonly sectors undergone merger and acquisition in Tanzania. A total of 75 companies were selected for this study. The study employ purposive sampling where banks, hotels 
INTERNATIONAL JOURNAL OF ACADEMIC RESEARCH IN BUSINESS AND SOCIAL SCIENCES

Vol. 8, No. 10, Oct. 2018, E-ISSN: 2222-6990 @ 2018 HRMARS

and telecommunication industries selected for this study was the ones which have undergone merger and acquisition.

\section{SERVQUAL MODEL}

The SERVQUAL model has been widely applied in measuring customer satisfaction in different ranges of service categories including hotels, tourism centers, parks and recreation services. However, it should be stated that despite its wide application, the model has notable deficiencies (Carman, 1990; Babakus \& Boller, 1992; Fick \& Ritchie, 1991). The service attributes that are used to measure service quality may not represent exact levels of service quality and/or may not measure all the important characteristics of a particular service. In addition, there are real limitations as related to interviewing respondents before and after the consumption of a given service; the so-called 'gap measure'. The service quality scores (SERVSC) that is obtained from the gap measurement of perceived and expected attributes may therefore turn out not to be a very reliable measurement of the service quality as it relates to visitor satisfaction.

However, from the perspective of a simple practical tool in alerting service providers and management to potential issues as relates to given services, the SERVQUAL model still possesses some values. Traditionally, SERVQUAL model was used to study level of consumer satisfaction on service industry. Currently we observe advance of the model in other areas for instance Yeboah. J et al (2015) link SERVQUAL with mergers and Acquisition. Also Burhan M (2014) uses SERVQUAL on studying investment attractions. But much observation of the advancement of the model was done by Nyeck. S et al (2012) by reviewing more than 40 articles which links SERVQUAL with other type of studies apart from customer satisfaction. In this regards, this study apply SERVQUAL model in measuring stakeholders perception and satisfaction in mergers and acquisition in Tanzania.

\section{Data Collection and Analysis}

Five (5) likert scale questionnaire to measure SERVQUAL was employed for this study. The questionnaire focused on measuring the perception and satisfaction of the stakeholders before and after mergers and acquisition. 75 questionnaires were supplied to banks, hotels and telecommunications companies where by $67 \%$ respond to the questionnaires. The use of the likert scale in mergers and acquisition studies with respect of SERVQUAL has been evidenced on the work of Yeboah, J et al (2015) and Nyeck, S et al (2012). Data analysis was done based by SERVQUAL procedures as proposed by Parasuramani et al (1988). 
INTERNATIONAL JOURNAL OF ACADEMIC RESEARCH IN BUSINESS AND SOCIAL SCIENCES

Vol. 8, No. 10, Oct. 2018, E-ISSN: 2222-6990 ㄷ 2018 HRMARS

\section{RESULTS AND DISCUSSION}

\section{Demographic Information}

This part solicits demographic information of the respondents and the variables used for the study. Reliability of the data was also measured in this part. This part presents demographic profiles of respondents used during the study. It includes gender information, age group and service sector category.

Table 2 Demographic Information

\begin{tabular}{|l|l|l|l|l|}
\hline variable & Frequency & Percent & Valid percent \\
\hline \multirow{4}{*}{ gender } & Male & 23 & 46 & 46 \\
\cline { 2 - 5 } & Female & 27 & 54 & 54 \\
\cline { 2 - 5 } & Total & 50 & 100 & 100.0 \\
\hline \multirow{4}{*}{ Age } & $18-29$ & 12 & 24 & 24 \\
\cline { 2 - 5 } & $30-41$ & 20 & 40 & 40 \\
\cline { 2 - 5 } & $42-53$ & 11 & 22 & 22 \\
\cline { 2 - 5 } & $54-65$ & 6 & 12 & 12 \\
\cline { 2 - 5 } & $>65$ & 1 & 2 & 2 \\
\cline { 2 - 5 } & Total & 50 & 100.0 & 100.0 \\
\hline \multirow{4}{*}{ Sector } & Bank & 16 & 32 & 32 \\
\cline { 2 - 5 } & Telecommunication & 25 & 50 & 50 \\
\cline { 2 - 5 } & Hotel & 9 & 18 & 18 \\
\cline { 2 - 5 } & Total & 50 & 100 & 100.0 \\
\hline
\end{tabular}

Source: Researcher's Field Data Analysis, 2017.

As seen from the table above, females were 27 (54\%) and males were 23 (46\%) slightly lower than females. Also most of the respondents in the age group of $30-40$ appeared by $40 \%$ of the total respondents, followed by $18-29$ (24\%), $42-53$ (22\%), 54-65 (12\%) and above 65years (2\%). Furthermore, most respondents indicated telecommunication sector as their service sector (50\%) followed by bank sector (32\%) and hotel sector (18\%). None of the respondents had indicated insurance sector as their service sector.

\section{Reliability of the Data}

To measure internal consistency of the data, Cronbach's Alpha coefficient measurement was employed. Consider table 4.2 and 4.3 below:

Table 4.2 Reliability Coefficient (Expectation Variables)

\begin{tabular}{|l|l|l|l|}
\hline Dimension & N of items & N of observations & Alpha \\
\hline Job creation & 5 & 50 & .885 \\
\hline Market monopoly & 3 & & .767 \\
\hline Customer satisfaction & 6 & 50 & .876 \\
\hline Shareholder position & 5 & 50 & .867 \\
\hline \multicolumn{2}{|l|}{ Overall Cronbach's Alpha } & .889 \\
\hline
\end{tabular}

Source: Researcher's Field Data Analysis, 2017 
INTERNATIONAL JOURNAL OF ACADEMIC RESEARCH IN BUSINESS AND SOCIAL SCIENCES Vol. 8, No. 10, Oct. 2018, E-ISSN: 2222-6990 @ 2018 HRMARS

.Table 4.3 Reliability Coefficient (Perception Variables)

\begin{tabular}{|l|l|l|l|}
\hline Dimension & N of items & N of observations & Alpha \\
\hline Job creation & 5 & 50 & .656 \\
\hline Market monopoly & 3 & 50 & .534 \\
\hline Customer satisfaction & 6 & 50 & .728 \\
\hline Shareholder position & 5 & 50 & .978 \\
\hline \multicolumn{2}{|l}{ Overall Cronbach's Alpha } & $\mathbf{. 8 7 8}$ \\
\hline
\end{tabular}

Source: Researcher's Field Data Analysis, 2017.

As seen in table 4.2 and table 4.3 above, reliability coefficients for both expectation and perception variables were above 0.5 . This indicates that dimensions of mergers and acquisition services were reliable and consistent for the study regarding stakeholders' perceptions on mergers and acquisition in Tanzania service sectors. Therefore, all items of service quality were retained for further analysis of the study.

\section{Gap Score Analysis}

Table 4.4 SERVQUAL Scores (Unweighted Average Calculated)

\begin{tabular}{|l|l|l|l|l|l|}
\hline Dimension & Statement & $\begin{array}{l}\text { Expectation } \\
\text { Score }\end{array}$ & $\begin{array}{l}\text { Perception } \\
\text { Score }\end{array}$ & Gap Score & $\begin{array}{l}\text { Average for } \\
\text { Dimension }\end{array}$ \\
\hline Job creation & 1 & 4.22 & 4.06 & -0.16 & -0.34 \\
\hline & 2 & 4.58 & 3.92 & -0.66 & \\
\hline & 3 & 4.28 & 4.22 & -0.06 & \\
\hline & 4 & 4.30 & 4.34 & 0.04 & \\
\hline Market monopoly & 5 & 4.50 & 3.64 & -0.86 & \\
\hline & 6 & 4.32 & 4.16 & -0.16 & -0.04 \\
\hline & 7 & 4.24 & 4.32 & 0.08 & \\
\hline Customer & 8 & 4.30 & 4.26 & -0.04 & \\
\hline satisfaction & & & & & \\
\hline & 9 & 4.10 & 3.82 & -0.28 & -0.13 \\
\hline & 10 & 4.12 & 4.06 & -0.06 & \\
\hline & 11 & 4.20 & 4.28 & 0.08 & \\
\hline & 12 & 4.44 & 4.08 & -0.36 & \\
\hline & 13 & 4.14 & 4.08 & -0.06 & \\
\hline Shareholder & 14 & 4.44 & 4.32 & -0.12 & \\
\hline & 15 & 4.40 & 4.20 & -0.20 & -0.15 \\
\hline & 16 & 4.48 & 4.16 & -0.32 & \\
\hline & 17 & 4.04 & 3.96 & -0.08 & \\
\hline & 18 & 4.02 & 3.90 & -0.12 & \\
\hline & 19 & 4.28 & 4.24 & -0.04 & \\
\hline Unweighted Average SERVQUAL score: & & & & -0.66 \\
\hline
\end{tabular}

Source: Researcher's Field Data Analysis, 2017. 
INTERNATIONAL JOURNAL OF ACADEMIC RESEARCH IN BUSINESS AND SOCIAL SCIENCES Vol. 8, No. 10, Oct. 2018, E-ISSN: 2222-6990 @ 2018 HRMARS

As indicated from the table above, stakeholders are less satisfied with every dimension of service quality of mergers and acquisition sectors in Tanzania. All items of service quality indicated a negative gap score expect for jb04 (creation of new culture that may cause misunderstandings), mm02 (market share increase due to new organization set up) and cs03 (improvement of product quality). Highest gap scores were employees' feeling of betray by their employers which also changes their work partners (-.86) and mergers and acquisition lay off employees in new setup (-.66) while the lowest gap scores were shift of bargain power from consumers to customers (-.04) and addition of sufficient value to stakeholders (.-04). Dimension with the highest average gap scores was job creation (-.34), while a dimension with the lowest gap score was market monopoly (-.04).

Table 4.5 Importance Weights

\begin{tabular}{|l|l|}
\hline Features & Points \\
\hline 1. Ability of create jobs & 51 \\
\hline 2. Monopoly of the market & 6 \\
\hline 3. Customer satisfaction & 20 \\
\hline 4. Position of shareholders & 23 \\
\hline Total: & 100 \\
\hline
\end{tabular}

Source: Researcher's Field Data Analysis, 2017.

As seen from the table, importance weights ranked high on mergers and acquisition job creation (51) followed by stakeholder's position (23) and customers' satisfaction (20). The lowest importance weight was on market monopoly (6). These results indicate that stakeholders were less satisfied with mergers and acquisition ability to create more job as they may have probably promised. Also position of stakeholders is also les important to mergers and acquisition as a result their bargaining power is depreciating.

Table 4.6 SERVQUAL Scores (Weighted Average Calculated)

\begin{tabular}{|l|l|l|l|}
\hline $\begin{array}{l}\text { SERVQUAL } \\
\text { Dimension }\end{array}$ & $\begin{array}{l}\text { Score from Table } \\
\mathbf{4 . 4}\end{array}$ & $\begin{array}{l}\text { Weighting from Table } \\
\mathbf{4 . 5}\end{array}$ & Weighted Score \\
\hline Job creation & -0.34 & 51 & -17.4 \\
\hline $\begin{array}{l}\text { Market } \\
\text { monopoly }\end{array}$ & -0.04 & 6 & -0.2 \\
\hline $\begin{array}{l}\text { Customer } \\
\text { satisfaction }\end{array}$ & -0.13 & 20 & -2.7 \\
\hline Shareholder & -0.15 & 23 & -3.5 \\
\hline Average Weighted score: & -23.7598 \\
\hline
\end{tabular}

Source: Researcher's Field Data Analysis, 2017.

As seen from the table above, weighted score indicates that job creation ranked high in stakeholders' dissatisfaction (-17.4). Other dimensions that showed less satisfaction to stakeholders include shareholders' positions (-3.5), customers' satisfaction (-2.7) and market monopoly (-.2). 
INTERNATIONAL JOURNAL OF ACADEMIC RESEARCH IN BUSINESS AND SOCIAL SCIENCES

Vol. 8, No. 10, Oct. 2018, E-ISSN: 2222-6990 @ 2018 HRMARS

\section{Conclusion and Recommendation}

This study intended to evaluate stakeholders' perceptions regarding mergers and acquisition in Tanzania service sector. Data from the study were collected from 100 respondents in various merged and acquired service companies in Dar es Salaam, Tanzania. The study employed SERVQUAL model to determine the level of stakeholders' satisfaction on mergers and acquisition dimensions namely job creation, market monopoly, customer satisfaction and shareholder position.

Major findings from the study indicate that stakeholders were not satisfied with every aspect of mergers and acquisition in Tanzania. Results from the gap score indicated that stakeholders perceived a negative satisfaction on mergers and acquisition in Tanzania service sectors. All dimensions of mergers and acquisition indicated a negative gap score meaning that none of them was reliable for stakeholders. Importance weight analysis indicated that job creation was highly expected by stakeholders but the actual response towards job creation was very low. This indicated that stakeholders obtained many job opportunities before mergers and acquisitions but those chances were less available after M\&A procedures.

Generally, the researcher recommends that merged and acquired service sectors in Tanzania to improve and increase stakeholders and customers' satisfaction by increasing more job opportunities, shares and flexibilities of market monopoly so to allow competition in the acquired market. This can be achieved through initial analysis of preexisting conditions before mergers and acquisition, its motives and expected results. Initial analysis is important as it can provide a road map on how to go through the process, challenges anticipated and contingent plans that will ensure that mergers and acquisition is beneficial to all stakeholders.

\section{References}

Babakus, E. \& Boller, G. W. (1992). An empirical assessment of the SERVQUAL scale. Journal of Business Research, 24 (3): 253-268.

Bekier, M. M. \& Shelton, M. J. 2002. Keeping your sales force after the merger. The McKinsey Quarterly, 4, 106- 115. [4] CAPRO

B. Hauser, Internal and External Context Specifi city of Leadership in M\&A Integration, BestMasters, DOI 10.1007/978-3-658-08077-8_2, C Springer Fachmedien Wiesbaden 2015

Carman, J. M. (1990). Consumer perceptions of service quality: An assessment of the SERVQUAL dimensions. Journal of Retailing, 66 (1): 33-55.

Chunlai C \& Findlay C (2003) A review of cross-border Mergers and Acquisitions in APEC, Asian- Pacific Economic Literature vol. 17, issue 2.

Fick, G. R., \& Ritchie, J. R. B. (1991). Measuring service quality in the travel and tourism industry. Journal of Travel Research, 30(2), 2-9.

Fosterreed S. A. L \& Nesvold, H.P (2007) The art of Mergers and Acquisitions, Fourth Edition; a merger Acquisition Buyout Guide MC Graw-Hill Education

Gaughan, P. A (2002) Mergers Acquisitions and Corporate restructuring. $3^{\text {rd }}$ edition New York. John Wiley \& Sons, Inc.

Grönroos, C. (1984) A service quality model and its marketing implications. European Journal of Marketing, 18(4), 36-44. 
INTERNATIONAL JOURNAL OF ACADEMIC RESEARCH IN BUSINESS AND SOCIAL SCIENCES

Vol. 8, No. 10, Oct. 2018, E-ISSN: 2222-6990 ㄷ 2018 HRMARS

Haspeslagh, C., \& Jemison, B. 1991. Managing acquisitions. Creating value through corporate renewal, New York: The Free Press.

Jagersma, P. K (2005) Cross border acquisitions of European Multinationas. Journal of General Management.

Mkono, N., \& Ache P., (2009) The rights to merge. Internatinal Financial Law Review

Nyeck, S., Morales, M., Ladhari, R. \& Pons, F. (2002). Ten years of service quality measurement; Reviewing the use of the SERVQUAL instruments

Oberg, C. \& Anderson, H. (2002) Do Customers matter in Mergers' and Acquisitions'.

Parasuraman, A., Zeithaml, V. A., Berry, L. L. (1988) SERVQUAL: A multiple-item scale for measuring consumer perceptions of service quality. Journal of Retailing, 64, 12-40.

Pilloff S. J \& Santomero A. M (1996) The value effects of Bank Mergers and Acquisitions, Centre for Financial Instituitions working papers, University of Pennsylvania

Ravenscraft D.J \& Scherer F. M (1987) Mergers, Sell-offs and Economics Efficiency, The brookings Institution Berkeley, CA

Selden, I. and Colvin, G. (2003) M \& A Needn't Be A Loser's Game. Havard Business Review, 81(6), 70. Vossos

Selden, L. and Colvin, G. (2003). M\&A Needn't Be A Loser's Game. Harvard Business Review, 81(6), 70. 